G. MENG, T. GUO, T. MA, J. ZHANG, Y. SHEN, K. B. SHARPLESS*, J. DONG* (SHANGHAI INSTITUTE OF ORGANIC CHEMISTRY, P. R. OF CHINA)

Modular Click Chemistry Libraries for Functional Screens using a Diazotizing Reagent

Nature 2019, 574, 86-89.

\title{
Click Chemistry for the Synthesis of Azides
}

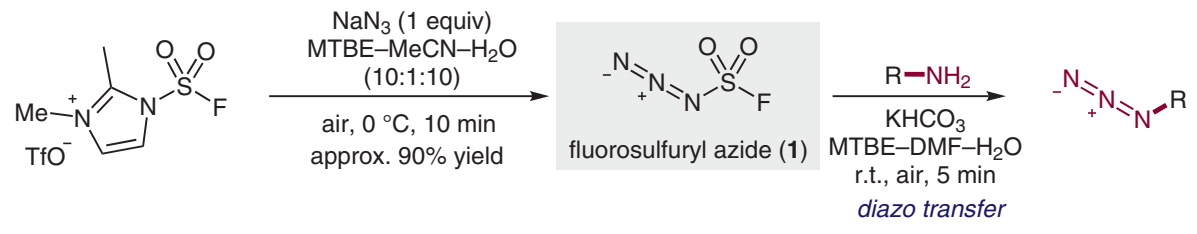

\section{Selected examples:}<smiles>CC1=C(C(=O)O)N2C(=O)C(NC(=O)[C@@H](N)c3ccccc3)[C@H]2SC1</smiles><smiles>COc1cccc2c1C(=O)c1c(O)c3c(c(O)c1C2=O)C(O)CC(O)(C(=O)CO)CC3O</smiles><smiles>CN(C)S(=O)(=O)N1CCN(c2ccc(F)cc2)CC1</smiles>
$96 \%$ yield<smiles>CCC</smiles><smiles>Nc1cccc2c1CN(C1CCC(=O)NC1=O)C2=O</smiles>

( \pm ); $88 \%$ yield<smiles>CCCCCCC(=O)NC(CCN)C(=O)NC(C(=O)NC(CCN)C(=O)NCC(C)C(C)CC)C(C)O</smiles>

mixture: $\mathrm{R}=\mathrm{H}$ (polymyxin $\mathrm{B} 1)$ Me (polymyxin B2)<smiles>C=C(C)[C@H](CCN)NC(=O)C(CC(C)C)NC(=O)CC(Cc1ccccc1)NC(=O)[C@H](CCN)NC(=O)[C@H](CCN)NC(C)=O</smiles>

\section{Key words}

diazo transfer

click chemistry

azides

chemical library
Significance: Copper-catalyzed azide alkyne click chemistry (CuAAC) is a powerful bioorthogonal reaction that provides triazole products in very high yields. A significant limitation is the restricted access to the azide precursors because azide preparation with $\mathrm{NaN}_{3}$ or $\mathrm{TfN}_{3}$ suffers from long reaction times, toxicity, or risk of explosion. The authors present a new, highly reactive diazo transfer reagent that enables rapid and safe access to azides from amines.
Comment: Previously reported fluorosulfuryl imidazolium triflate salt (Guo et al. Angew. Chem. Int. Ed. 2018, 57, 2605) was treated with $\mathrm{NaN}_{3}$ to generate fluorosulfuryl azide $\mathbf{1}$ in situ. In an optimized solvent system (DMF-MTBE- $\mathrm{H}_{2} \mathrm{O}$ ), 1 undergoes diazo transfer to a broad variety of amines in a click chemistry fashion. 